\title{
Study of the effect of crude extracts and oil extract for the seeds of the (Carum carvi L.)plant on the cancerous cellular lines L20B and SR
}

\author{
Nasr Aafit Alobaidy ${ }^{1}$ Hameed Hussein Ali ${ }^{2}$ Zaid A. Thabit ${ }^{3}$ \\ 1 Department of Medical Laboratory Techniques, AL-Maaref University College \\ 2 Department of chemistry, College of Science, University of Anbar \\ 3 Biotechnology Research Center, University of AL-Nahrain
}

\section{Article Info}

Received:, 2019

Revised:,2019

Accepted:,2019

\section{Keywords}

Caraway, GC-Mass, L20B, $\mathrm{SR}$, extraction, cancer

Corresponding Author

Nasr91er@gmail.com

\begin{abstract}
Caraway (Carum carvi L.) is an important medicinal plant that contains a range of bioactive compounds. The extraction process was carried out using four separate solvents: $70 \%$ methanol, $70 \%$ ethanol, $70 \%$ hexane, and water by continuous extraction using the Soxhlet device, has been chemical detection of effective ingredients in crude extracts. The volatile oils were also extracted by the aqueous distillation method using the Clevenger device and the chemical compounds found there were detected using GC-Mass technique. The study has been effect of active Components for the crude extracts and oil extracted for the seeds of the Caraway plant on the growth of the L20B,SR cancerous cellular lines out of the living body (in vitro) using two concentrations (12.5, 25) $\mu \mathrm{g} / \mathrm{ml}$ within a 72-hour exposure period. The results showed a incorporeally difference and a probability level of $\mathrm{P}<0.05$ for some crud extracts. Where the highest rate of inhibition on the cancerous cell line L20B at the concentration of $12.5 \mu \mathrm{g} / \mathrm{ml}$ for ethanol extract of $29.7 \%$, as for the SR cancerous cell line, it was the highest inhibition for extract Hot water at low concentration of $73.28 \%$. The extracted oil also had an effect on the growth of the cancer cell lines under study. The objective of this study is to test the toxicity of crud extracts and oil to the seeds of the Caraway plant on the L20B and SR, and to know the amount of oil in the seeds of the Caraway plant
\end{abstract}

\section{Introduction}

Plants have contributed since thousands of years and continue to make an effective contribution to the health and quality of life of human communities, herbs have been used by ancient civilizations in treating diseases and in improving the value and flavor of food, and to contain these herbs on many anti-oxidant compounds, bacteria, fungi, cancerous diseases, etc , in response to the phenomenal growth in the food industry sector, demand for these herbs has grown dramatically, as these plants contain many substances that act as antibiotics for the growth of microbiology and cancerous cells, in addition, these plants contain vital and important compounds in the pharmaceutical industry (Meena et al., 2010) . Of these medicinal plants is the (Carum carvi L.) plant of perennial plants which characterized with its thick roots, composite leaves and white flowers Small and low-spreading fruits, It is a double-edged 
herbaceous plant with a root, a pedicle and a branched trunk, and its many leaves are winged with winged fruits (Keshavarz et al., 2013) . In the Middle Ages, the crocodile was cultivated in Sicily and the Scandinavian Peninsula. It has been widely used and used for various industrial purposes and has been commercially grown in the Netherlands, Germany, Poland, Ukraine, Hungary, Romania, Sweden, Norway, Spain and Austria. Its production also flourishes in other parts of the world such as Canada, the United States, Morocco, Syria and Morocco grow annual varieties, while the production of converted models in the countries of Central Europe and Western countries for their simple environmental needs and high value as well as flourishing in Iran and Iraq (Begum et al., 2008) . It is also grown in Asia, North Africa, Aruba, California, Indonesia, North America, Russia, and India. The United States is also the largest producer of Caraway for 2006 (Nicola et al., 2005 and Johri,2011). Caraway is called Cumin des press (France and Italy), Kummel in Germany, Alcaravea in Spain, Karriy in the Netherlands, Kminek in Poland and Komeny in Hungary, Each European country has its own name, but it is derived from the Arabic word Caraway (Keshavarz et al., 2013 and Al-Janabi, 2018). The medicinal and nutritional value of caraway seeds depends on the nature of the components found in the seeds of this plant. Plant seeds contain proteins, resins, glycosides, tannins, saponins, flavonoids, and phenols, the most important of which are thymol, Eugenol or Carvacrol (Katarzyna et al., 2013 and Sedlacova et al., 2003). Cancer cell lines provide cancer researchers with a large number of cancer cells. These lines have been used to study the toxic drug effectiveness of experimental treatments used against cancer to significantly control the physiological, chemical and physical environment as well as control the drug concentration and exposure time compared to the experimental process within the living body (Freshney, 2001). In recent years, researchers have looked at the compounds in medicinal herbs in an attempt to treat cancer. These studies have succeeded in using plant extracts and their active compounds in inhibiting the lines of cancer cells, including the study done by Lopoz and his group (Lopoz et al., 2003).

\section{Material and methods \\ 2.1: Plant Collection and Extraction}

Samples of the seeds of the plant were collected from the herbaceous medicinal plants in the $\mathrm{Bab}$ AL- Muatheam - Baghdad - Iraq and were classified in the college of Science, University of Baghdad. Samples of Caraway seeds were brought to the laboratory where they were thoroughly cleaned from the soil. After drying at $25 \mathrm{C}^{\circ}$, they were grinded with an electric mill and then filled in sterile tightly sealed containers and kept away from direct light in the refrigerator until use. $50 \mathrm{~g}$ of dried plant seed powder, placed in Thimpel in Soxhlet and used $400 \mathrm{ml}$ of solvents each separately (70\% methanol, $70 \%$ ethanol, hexane and water) for eight hours and soak $50 \mathrm{~g}$ in $400 \mathrm{~mL}$ water Distilled for 48 hours. The extracts were then filtered using the Vacum pressure and filter paper. The extracts were then concentrated using rotary evaporator at a temperature of $45^{\circ} \mathrm{C}$ for all extracts other than water, dried with an oven of $65^{\circ}$ C. Concentrated extracts were transferred, weighted and estimated at the percentage of the following formula:

$$
\text { Yield extract }=\frac{\text { Weight of the concentrated extract }}{\text { Weight of dry plant powder }} \times \% 100
$$

They were transported to appropriate sterile containers and kept in the refrigerator at $4 \mathrm{C}^{\circ}$ until use (Petraitytè and Dastikaitè, 2007).

\section{2 :Extraction of volatile oils}

The volatile oils were extracted using a Clevenger device, placing $50 \mathrm{~g}$ of plant powder with $250 \mathrm{ml}$ of distilled water, extraction was performed for 4 hours and the accumulated oil was separated and stored in dark, sterile glass bottles until use (Kato et al., 1999). The active compounds found in the Caraway oil were discovered using GC-Mass and the conditions used in this technique are:

Carriar gas: Helium

Flower rate : $0.5 \mathrm{ml} / \mathrm{min}$ at a split vatro of $1: 10$

Temperature program : 40Co for $1 \mathrm{~min}$, rising at $4 \mathrm{Co} / \mathrm{min}$ to $150 \mathrm{CO}$ and held for $6 \mathrm{~min}$, rising at $4 \mathrm{CO} / \mathrm{min}$ to $200 \mathrm{Co}$ and held for $1 \mathrm{~min}$.

Column : optimo17 mid. Polarity 30/0.5 . 
Injector detector were held at $200 \mathrm{~mL}$ and $200 \mathrm{Co}$

Mass spectro were obtaind by Electron Ionization (EI) at $70 \mathrm{ev}$ using a spectral range of $\mathrm{M} / \mathrm{Z} 45-450$.

\section{3: Phytochemical tests}

1- Tannins test : Add a few drops of $1 \%$ ferric chloride solution to the water extract of the plant and when a greenish blue color indicates the presence of tannins (Kelmanson et al., 2000 ).

2- Glycosides test: Mix $1 \mathrm{~mL}$ of the plant extract with $2 \mathrm{ml}$ of Benedict's reagent. Mix in boiling water bath for 5 minutes and leave solution to cool when red deposits indicate glycosides (Eslah et al., 2016).

3- Alkloids test : Add 1-2 mL of Drkandarov reagent to $5 \mathrm{ml}$ of water extract and the appearance of a reddish orange color indicates the presence of alkaloids (Bouaklin et al., 2000). 4- Saponin test : Add $3 \mathrm{ml}$ of $1 \%$ mercuric chloride solution to $3 \mathrm{ml}$ of water extract and leave for 10-5 minutes, a white precipitation indicating the presence of Saponin (Melvinjoe et al., 2000).

5- Flavonoids test : Add $5 \mathrm{ml}$ of diluted ammonia(3M) to $10 \mathrm{ml}$ of plant extract, then add a few drops of concentrated sulfuric acid and yellow color to indicate the presence of flavonoids (Wainstein et al., 1995).

6- Phenolic test : Add $2 \mathrm{ml}$ of $1 \%$ ferric chloride to $3 \mathrm{ml}$ of water extract and then add $2 \mathrm{ml}$ of $1 \%$ potassium cyanide to the mixture. A dark bluishgreen color indicates the presence of phenols (Roberts and Wink, 1998).

7- Resin test : Add $50 \mathrm{ml}$ of ethyl alcohol to $5 \mathrm{~g}$ of plant powder and leave in a boiling water bath for 2 minutes and then aspirate $20 \mathrm{ml}$ of distilled water with $4 \%$ hydrochloric acid, Where it is observed that the turbidity is indicative of the presence of resins (Melvinjoe et al., 2000).

8- Terpenoides test : Add $5 \mathrm{ml}$ of water extract to $2 \mathrm{~mL}$ of chloroform followed by $3 \mathrm{ml}$ of concentrated sulfuric acid with caution on the inner wall of the test tube where a reddish-brown separating layer forms a sign of the presence of turbines (Roberts and Wink, 1998).

9- Amino acids test : Add two drops of $0.2 \%$ Ninhydrin to $1 \mathrm{ml}$ of the plant extract and place the test tube in a boiling water bath for 2 minutes, a purple or yellow color indicating the presence of amino acids (Eslah et al., 2016).

\section{4: Study of the effect of crude extracts} and oil for the Caraway plant on cancerous cellular lines

Was completed in this research, the study of the effect of crude extracts and oil on the seeds of the Caraway plant on two lines of cancer cell, $120 \mathrm{~b}$ is a cell intestines for female mice type Albino mice and SR which is the term of lymphocytes surrounding the lung in humans and is prepared by the Biotechnology Research Center - AL-Nahrain University.

\subsection{1: The solutions Special tissue culture and secondary culture}

The solutions were prepared according to the ( Freshney) method of tissue culture (Freshney, 2012).

\subsubsection{1:Tissue culture media:}

The culture Media (RPMI-1640) Rosweel Park Memorial Institute and its consists of :

$10.4 \mathrm{~g}$ RPMI- 1640 with hepes buffer , L.glutamine

$15 \mathrm{~g}$ of sodium bicarbonate to adjust $\mathrm{PH}$ to 7.4 -7.8 .

$0.5 \mathrm{ml}$ of Crystilline Penicilline .

$0.5 \mathrm{ml}$ of Streptomycin .

$0.5 \mathrm{ml}$ of Nystatin .

$5 \%$ of the bovine serum .

Complete the size to one liter by adding distilled water and sterilizing by filtering using a diameter of $0.22 \mu \mathrm{m}$ filter under sterile conditions .

\subsubsection{2: secondary culture media :}

Contains all the components of the grazing medium mentioned in paragraph (1) except for the bovine serum.

\subsubsection{3: Solutions used in genetic-cellular study}

1- Solutions Phosphate Buffer Saline ( PBS) : The solution prepare with dissolve 8 grams of sodium chloride, $0.2 \mathrm{~g}$ of potassium chloride, $1.15 \mathrm{~g}$ sodium phosphate mono-hydrogen and $0.2 \mathrm{~g}$ phosphate potassium dihydrogen in 1000 $\mathrm{ml}$ of distilled water and adjusts under $\mathrm{PH} 7.2$ 
and then sterilized with use autoclave with a temperature of $121 \mathrm{CO}$ for 15 minutes and saves In 4 CO until use (Allen, 2005).

2- Sodium bicarbonate solution : This solution was prepared by dissolving 7.5 grams of Sodium bicarbonate in $1000 \mathrm{ml}$ of distilled water to get a concentration of $0.75 \%$ and then sterilize with use autoclave at temperature of $121 \mathrm{CO}$ for 15 minutes, this solution is maintained at $4{ }^{\circ} \mathrm{c}$ until use (Allen, 2005).

3. Preparation of a dye MTT: Dissolved are 50 mg of MTT dye in $100 \mathrm{ml}$ of Phosphate Buffer Saline (PBS) and then nominated by a filter paper and then sterilized by use filter with a diameter of $0.22 \mu \mathrm{m}$ (Freshney, 2012).

4- Preparation of Trypsin : Prepared one gram of trypsin powder in $100 \mathrm{ml}$ of the (PBS) solution, prepared in paragraph (a), sterilized by a filtration with use filter in diameter $(0.22 \mu \mathrm{m})$ and save to a degree $-20 \mathrm{CO}$.

5- Preparation Versine : Added one gram of powder EDTA (Ethylene diamine tetra acetic acid disodum) to $100 \mathrm{ml}$ of distilled water and its dissolve well and then sterilized with use of the autoclave at $121 \mathrm{CO}$ for 10 minutes and save at $20 \mathrm{CO}$.

6- Trypsin-Versine solution consists of :

1- $20 \mathrm{ml}$ of Trypsin solution .

2- $10 \mathrm{ml}$ of Versine solution .

3- $370 \mathrm{ml}$ of PBS solution .

The materials were blended together and preserved at a temperature of $4 \mathrm{CO}$ until use. 7- DMSO solution: Its prepared by mixing 0.2 $\mathrm{ml}$ of DMSO in $100 \mathrm{ml}$ of distilled water, then sterilized using a filter with holes in diameter $0.22 \mu \mathrm{m}$ and save at $4 \mathrm{CO}$ until use.

8- Nystatin Solution : Its prepared by addition of half a pill of $500 \mathrm{mg}$ of Nystatin to the media and dissolve it.

9- Streptomysin Solution : It was prepared to dissolve one gram of Streptomysin in $5 \mathrm{ml}$ of distilled water to be the final concentration of $200 \mathrm{mg} / \mathrm{ml}$, then take $0.5 \mathrm{ml}$ and add to one liter of the culture medium.

10- Penicillin solution : It was prepared to dissolve one gram of penicillin in $5 \mathrm{ml}$ of distilled water and $0.5 \mathrm{ml}$ is added to one liter from the culture medium.

2.4.1.4: Preparation of the medium culture of the cancerous cellular lines and testing of the toxicity of the extracts on those lines

\subsubsection{1- Preparation of the medium} culture of the cancerous cellular lines

The culture medium was initialized in paragraph (a) according to the method of ( Freshney) (Freshney,2012 ), mixing its ingredients with each other to prepare one liter of it, and then sterilize with a candidate with a perforations 0.22 $\mu \mathrm{m}$, the medium was then distributed in glass bottles with a Airtight cover of $200 \mathrm{ml}$ and was preserved at 20-mm until use.

The steps for tissue transplantation were carried out under sterile conditions, as follows:

1- $2 \mathrm{ml}$ of the Trypsin/ Versine solution was added to the $25 \mathrm{~cm} 3$ Tissue culture bottle containing cells after discharge from the Tissue culture medium and then the bottle was gently moved and incubate at the incubator at $37 \mathrm{CO}$ for 15 minutes to dismantle the glued cells as well as to glue it to the wall of the bottle to get As much as possible on single mono cells.

2- The bottle containing the broken cells was added approximately $15 \mathrm{ml}$ of new growth (RPMI-1640) and the bottle was moved well and then emptied the contents of the bottle which content on the new medium culture of the cell are combined with the cells into another new bottle so that the level of the culture media with the cells is equal between the two bottles Each bottle is put the same size in the middle culture with cells and is called the subculture .

3- The bottles were incubate at a temperature of $37 \mathrm{CO}$ for two days with respect to $120 \mathrm{~b}$ and SR and the bottles were followed daily to make sure that they were free of any pollution and that the cells in good condition by examining the inverted microscope and when the growth inside the bottle becomes well, the cells are ready to use.

\subsubsection{2: Testing the toxicity of crude extracts on the proliferation of cancer cells:}

The extracts (cold water, hot water, methanol, ethanol, hexane) was prepared for the Caraway plant in accordance with paragraph (A). The extracts were sterilized using a $0.22 \mu \mathrm{l}$ filter. Two concentrations ( 25 and $12.5 \mu \mathrm{g} / \mathrm{ml}$ ) were present under sterile conditions The 
concentrations prepared immediately after the completion of the preparation process and according to the following steps:

1- Prepare the cell suspension by treating tissue culture size $25 \mathrm{~cm} 3$ with Trypsin/ Versine solution after unloading the old plant medium and gently moving the bottle, incubated in the incubator at $37 \mathrm{C}^{\circ}$ for 15 minutes, then add 20 $\mathrm{ml}$ in the RPMI-1640 growth medium and mix stuck cells well. After each new blending, $0.2 \mathrm{ml}$ were transferred to the Microtiter plate for tissue culture calibration using a fine automatic pipette.

2. Remained the dish in the incubator at a temperature of $37 \mathrm{C}^{\circ}$ for 24 hours until the cells are attached to the hole. The old culture medium is then removed from the hole and $0.2 \mathrm{ml}$ of the previously prepared concentrations were added in each hole and three replicates each concentration. Three replicates were performed for control (cells only) with a with a culture medium without serum (free medium ).

3- After 24 hours, remove the dish from the incubator and add a MTT dye solution

3- $\quad[4, \quad 5$-dimethylthiazoyl $] \quad-2, \quad 5-$ diphenyltetrazolium bromide (MTT dye)

For all holes containing cell $0.2 \mathrm{~mL}$ each hole. 4 - the dish was returned to the incubator to incubate for two hours, and then removed the dish and removed the dead cells as the living cells take the dye of the dead do not take them and then treated with a solution DMSO.

5- The results were read using ELISA with a wavelength of $630 \mathrm{~nm}$.

6- The inhibition ratio for each concentration was calculated using the equation :

$\% \mathrm{IR}=\frac{\frac{A-B}{A}}{\mathrm{~A}=\text { Control }} \mathrm{X} 100$
$\mathrm{~B}=$ Test

\section{5: Statistical analysis:}

Statistical analysis was carried out by Graphpad prism v6. The ANOVA and Correlation coefficients were used to compare the results of the study.

\section{Results:}

\section{1: Plant Collection and Extraction :}

Table (1) shows the quantity and percentage of extracts obtained after extraction.

\section{2: Phytochemical tests:}

Table ( 2) shows the results of the chemical detection of active compounds in the seeds of the caraway plant:

\section{3:Qualitative and Quantitative Diagnosis of Chemical Compounds in Caraway Seed Oil}

Table (3) shows some of the chemical compounds that have been identified in caraway seed oil.

\section{4: Study the effect of crude extracts and oil on cancer cell lines (L20B, SR)}

\subsection{1: The effect of crude extracts and oil on the cancer cell line L20-B}

Table (4) shows the percentages of inhibition of L20-B Cancer cells using different solvents and different concentrations.

\subsection{2: Effect of caraway plant extracts on cancer cell line $\mathbf{S R}$}

Table (5) shows the percentages of inhibition of SR cancer cells using different solvents and different concentrations.

\section{Discussion}

The results of the study showed that each $50 \mathrm{~g}$ of dried plant seed powder after extraction was obtained quantities in Table (1), where the quantity obtained was different according to the solvent used in the extraction process and the highest percentage of extraction using cold water. The quantity of oil obtained After extraction, it was $3.45 \%$ for $50 \mathrm{~g}$ of plant powder.

The results of the analysis and the specific chemical analyzes of the crude water extracts of the seeds of the caraway plant show that the cold water extract contains the active compounds (Soponine, glycosides, carbohydrates, tannins, alkaloids, flavonoids, resins, turbines and phenols), while the Hot water extract contains the active compounds (Tannins, flavonoids, resins, amino acids and phenols) (as in Table 2). Alcohol extracts contain active substances as shown in Table (2). Methyl extract contains 
active compounds (Soponine, tannins, flavonoids, resins, turbines, amino acids and phenols). Ethyl extract contains active compounds (Soponine, tannins, flavonoids, Resins, amino acids and phenols). The hexane extract contains active compounds (Soponine, alkaloids, resins, turbines and amino acids).

The presence of these effective compounds explains the importance of these plants and the reason for their use in medicine as well as reveals the medicinal value of these plants and these results are identical to previous studies in containing these plants on the active compounds (Johri , 2011 and Johri et al.,2014 and Kalita and Haque, 2012 and Chibueze et al., 2012 ) which calls attention to these plants why It has a medicinal and therapeutic value. And that the detection, isolation and purification of these compounds has an effective effect in the use of their results for the purpose of use in the control of human diseases caused by bacteria, fungi, cancer and others the crude alcohol and water extracts of the seeds of the caraway plant contain flavonoids, which have been shown to have high biological and physiological efficacy when given orally, which act as antioxidants that protect the cells from free radicals of the oxygen and which is working to remove them (Nakayama et al., 2002).

The toxic effect of caraway extracts on cancer cells outside the organism has been shown to contain active compounds that may have a direct or indirect role in the effect. These effects have the effect of sustaining cancer cell lines outside or inside the organism, so they are prepared as therapeutic agents For cancer, the most important flavonoid compounds are Apigenin, Luteolin, Quercetin and others (Abdel-Massih et al., 2009) . These compounds have been shown to have a toxic effect on the growth of cancer cell lines. Quercetin plays an important role in the inhibition of cancer cell carcinoma colon carcinoma HT-29 and leukemia HL-60 in humans (Kuo, 1996).

The presence of tannins in L. marianum silybum extracts affects cancer cell lines by fragmenting the DNA and encouraging cells to die apoptosis as well as acting as antioxidants by removing the free radicals generated when cancer cells form (Omenu , 1995). Sadeghi (and his group) concluded that the isolated turbines from the
Daphne mucronata plant had an inhibition role on the Human myelogenous Leukemia K562 by stopping the cellular cycle at phase -G1 (Sadeghi and Yazdan , 2003).

The results of the study of the effect of flavonoids, tannins and terpenes on cancer cell growth are consistent with the results of this study through the toxic effect of crude extracts on the growth of cancer cell lines L20B and SR because it is rich in these compounds and has anti-cancer effect.

The analysis of the seeds of the coriander plant in the GC-Mass as shown in Table (3) Figure (1) that the caraway seed oil contains many chemical compounds. Carvone has the highest ratio of the other compounds, While the compound of transB-ocimene was the lowest relative to the rest of the chemical compounds.

Another study indicated that the biological effectiveness of caraway oil is attributed to the fact that it contains many effective chemical compounds, especially Carvone, which is found in a high percentage of the other compounds found in caraway oil, which is $76.78 \%$, and that this compound of great medicinal importance it helps in The carvone is a tonic for blood circulation and anti-rot. It is also used to purify the digestive system, fever and typhoid cases. It also has a preservative against bacteria and fungi and has the effect of inhibiting or reducing the growth of cancer cells (Salimon and Badeaa, 2002 and Locobe et al.,2005).

L20B was treated with different concentrations $(12.5,25 \mu \mathrm{g} / \mathrm{ml})$ from the caraway plant extracts and there was a clear inhibitory effect of some extracts, and this inhibition varies with the concentration percentages used it is noted from Figure (2) Table (4) that the water extract has no inhibitory effect on the cancer cells in the cell line (L20B), while the alcohol extracts gave ethanol the highest inhibition rate of $29.7 \%$ at the concentration of $12.5 \mu \mathrm{g} / \mathrm{ml}$ followed by the oil given $(13.33 \%, 12.12 \%)$ at concentration $(12.5$ and 25) $\mu \mathrm{g} / \mathrm{ml}$, respectively, while the hexane extract did not affect the growth of cancer cells.

The results of the statistical analysis showed no significant difference between the concentration of hot and cold water extract and the hexane extract at the probability level $\mathrm{P} \leq 0.05$. There was a significant difference between the concentrations of ethanol extract at the 
probability level $(\mathrm{P} \leq 0.05)$, as well as the extract of methanol and caraway oil gave a significant difference at the probability level $(\mathrm{P} \leq 0.05)$.

Previous studies have indicated that the ability of methanol and ethanol alcohol to precipitate many active compounds, including flavonoids, which are aromatic compounds containing hydroxyl groups, is free and multiple. The inhibitory capacity of these compounds increases by increasing these groups by forming hydrogen bonds between the hydroxyl groups of the compound and aggregates Sulfur of the cell protein, which changes the nature of the cellular proteins causing deposition and loss of function (Locobe et al.,2005). The effectiveness of the caraway oil towards these cells is attributed to the fact that it contains many high-efficiency chemical compounds, especially Carvone, which amounted to $76.78 \%$ (Fabio et al., 2003).

When the cancer cell line SR was treated with different concentrations of caraway extracts, it was found that there is a clear inhibitory effect of some extracts on this type of cancer cells. This inhibiting varies with different concentrations.

It is noted from Figure (3) Table (5) that the cold water extract did not give any inhibiting or killing rate of the SR type cancer cells at both concentrations used. The hot water extract gave an inhibition rate of $73.28 \%$ at concentration $12.5 \mu \mathrm{g} / \mathrm{mL}$ the highest rate of inhibition of cancer cells SR type for the extracts of the caraway, and the rate of inhibition of $58.62 \%$ at the concentration $25 \mu \mathrm{g} / \mathrm{ml}$, and the difference in the rates of inhibition of water extracts note that the extract of hot water more effective in killing cancer cells, may be due to the ability of hot water to precipitate Some chemical compounds are more effective in killing cancer cells than cold water (Linnebacher et al., 2010). Alcohol extracts showed that the methanol extract did not give any kill rate to cancer cells at both concentrations. The ethanol extract gave a killing rate of $11.2 \%$ at $12.5 \mathrm{mg} / \mathrm{ml}$ and no kill at $25 \mu \mathrm{g} / \mathrm{mL}$. The hexane extract gave $19.8 \%$ inhibition at $12.5 \mu \mathrm{g} / \mathrm{mL}$, and did not give a kill rate of cancer cells at $25 \mu \mathrm{g} / \mathrm{ml}$. In the caraway oil, the rate of inhibition of cancer cells was $26 \%$ at $12.5 \mathrm{mg} / \mathrm{ml}$ concentration and $19 \%$ at $25 \mu \mathrm{g} /$ $\mathrm{ml}$. The results of the statistical analysis showed that there was a significant difference between the concentration of cold water extract at the probability level $\mathrm{P} \leq 0.05$. There is also a significant difference between the concentration of the extracts of ethanol, hexane and oil at the level of probability $\mathrm{P} \leq 0.05$. The most acceptable explanation for the toxic effects of plant extracts toward cancer cells is their ability to stimulate cell programmed death and to try to stop their proliferation, many nutrients and medicinal herbs have toxic effects in cancer cells by urging them to die programmed (Rimute , 2012) .

The coriander's ability to inhibit cancer cells has been attributed to the fact that it contains Eugenol type of phenolic compound (Olatunde and Dikwa, 2014) . Phenolic compounds have many effects, including the antioxidant effects of cancer cell growth largely because they have the ability to scavenge the free radicals generated when natural cells are transformed into cancerous cells. These compounds contain a group of hydroxyl-3, which can increase their ability to clear the free radicals generated in cancer cells and then direct the cell to enter the stage of programmed death, among the lines that inhibit these compounds are: HEP- 2 and (BC1) carcinoma of breast and human colon cancer (CASK1) and human prostate carcinoma (DV145) (Thatte et al.,2000).

\section{References}

1- Meena, A. K., Singh, B., Yadav, A. K., Singh, U., Kaur, R., Sachan, A., Gautam, V. \& Pal, B. (2010). Review on medicinal properties and bioactive constituents of herbal spices commonly used in India. Journal Pharm Res., 3(4), 866-868. 2. Keshavarz, A., Minaiyan1, M., Ghannadi, A. \& Mahzouni, P. (2013). Effects of Carum carvi L. (Caraway) extract and essential oil on TNBSinduced colitis in rats. Journal List Res Pharm Sciv, 8(1), 1-8.

3- Begum, J., Bhuiyan, M. N., Chowdhury, J. U., Nuzmul-Hoque, M., \& Anwar, M. N.(2008). Antimicrobial activity of essential oil from of Carum carvi and its composition Bangladesh. Journal Microbiol, 25(2), 85-89. 4- Nicola S. Iacobellis, Pietro L., C., Francesco C. \& Felice S. (2005) . Antibacterial Activity of Cuminum cyminum L. and Carum carvi L. Essential Oils. Journal, Agric. Food Chem., 53, 57-61. 
5- Johri, R. K . (2011) . Cuminum cyminum and Carum carvi. Jan-Jun, 5(9), 63-72 .

6- Al-Janabi, M. (2018) . Antibacterial Activity Of Caraway seeds and Indian costus roots essential oils. G.J.B.B., 7 (1) , 44 - 48.

7- Katarzyna S., Ł., Bogdan K., Elżbieta K. \& Jan B.(2013). Microbiological activity of caraway (Carum carvi L.) essential oil obtained from different origin. Journal, Acta Scientiarum, $35,4,495-500$.

8- Sedlakova, J., Kocourkova, B., Lojkova, L. \& Kuban, V. ( 2003) . The essential oil content in caraway species (Carum carvi L). Hort . SCI. (PRAGUE), 30(2), 73-79.

9- Freshney, J. M. (2001). Application of cell culture to toxicology. Cell Biology and Toxicology, 17, 213-230.

10 - Lopoz -Lazaro, M., Palma, D. I. , Pera, N., Pastor, N., Marlin-Cordero, C. , Navarro, E. , Corler, F., Ayso, M. J. \& Toro, M.V.(2003). Antitumor activity of digitalis purpurea L. subsp. Heywoodii .Plant Med.,69,701-704.

11- Petraitytè, N., Dastikaitè, A. , (2007) . Agrobiological assessment of wild Carum carvi Lcenopopulation biodiversity ex situ . Biologija, 53, 4, 74-79.

$12-$

Kato , M. , Mizuno , K. , Fujimura , T. , Iwama , M. , Irie , M. , Crozier , A. \& Ashihara , H. ( 1999). Purification and characterization of caffeine synthase from tea leaves. Plant physiology, 12, $579-586$.

13- Kelmanson, J. E., Jager, A. K. \& Staden, T. V. (2000) . Zulu medicinal plant with antibacterial activity. Journal Ethno pharmcal, 69, $241-246$.

14- Eslah S. R., Khlood W. A. \& Zaynab Y. M. H. (2016) .Purification and Identification of Flavonoids Extracted from Loranthus Eurpaeus Fruits. Journal of Biotechnology Researches Center, , 10 (1), ,1815-1140.

15- Bouaklin, A., Lacroix, C. , Roux, N., Gangheux, J. P. \& Deronin, F. (2000). Fungal contamination of food in Dermatology units. Journal, Clin . Microbilogy , 38 , 4272- 4273.

16- Melvinjoe, M. , Jayachiyral, J. \& viyayaprixa, M. (2000). Candida and Candisis. 3rded. Journal of medicinal and plant Research, 3(11), 1134- 1136.

17-Mark, A. W., Richard, C. G., J. R. \& Martin, I. R. (1995). Prdispasing factors of systemic fungal in fections of genitourinary tract. Journal of Uholwy, 154, 160-163.

18- Roberts, M. \& Wink, M. (1998). Alkaloids Biochemistry Ecology and Medicinal application. plenum press New York- London , 435-459.

19- Freshney, R.I., (2012). Culture of animal cell. 6nd ed., Wily- Liss, NewYork .

20- Allen, J., W., Schuler, C., F., Mends, R., W. \& Latt, S., A., (2005). Asimplified technique for in vivo analysis of sister chromatid exchange using 5-bromodeoxy uridine tablest, cytogentics. ,18, 231-237.

21- Johri, R., K. (2011). Cuminum Cyminum and Carum carvi:Anupdate. Pharmacogen Rev. , 5(9) , 63-72.

22- Johri G., K., Abdullah, S., S., Kumari, P., S. (2014). Antidiabetic Effect of Costus speciosus Rhizome Extract in Alloxan Induced Albino Rats. Journal of chemistry and biochemistry , 2(1) ,13-22 .

23- Choudhury, N., Kalita, J., C. \& Haque, A., (2012). " Effect Of Costus Speciosus Koen on Reproductive organs of Female Albino Mice . Internationl Reseach journal of pharmacy , 3(4), $200-202$.

24- Chibueze, F., U., Kingley, N., A., Okorie, K., N., Agwu, A. \& Success, N., N. (2012). Phytochemical Composition Of Costus Afer Extract and its Alleviation of Carbon Tetrachloride-induced Hepatic oxidative Stress and Toxicity. International Journal of Modern Botany , 2(5) ,120-126.

25- Nakayama, T., Hor, K., T. \& Kawakish. S., (2009). Comparision of the Cytotoxicity Of different hydroperoxides to v79cell. Free Radical Res. Communications , 14(3) , 173-178.

26- Abdel-Massih, R., M., Fares, R., Bazz, S., EL-Chami, N. \& Baydoun, E.(2009). The apoptotic and anti-proliferative activity of origanum majorana extracts on human Leukemic cell line. Leuk Research, 34(8), 41-48.

27- Moon, Y., J., Wange, X. \& Morris, M., E. (2006). Dietary flavonoids: effects on xenobiotic and carcinogen metabolism. Toixcal in vitro, 20(2) , 187-210.

28- Omenu, G. S.(1995). What accounts for the association of vegetables and fruits with lower incidence of cancers and coronary heart diseases . Ann Epideimal., 5(4), 333-5. 
29- Sadeghi, H. \& Yazdan, P., R. (2003). Antitumor activity and cell cycle arrest of a new diterpene ester from Dophne mucronala using K562 cell. Biomed Journal, 7(3),127-131.

30- Salimon K.M, \& Badeaa, R.I., (2002). Effect of oil Extracted from some medical plants on differe mycotoxigenic fungi. Journal Food chem. Toxicol, 40(11), 1669 - 1675. 31- Locobe LLi , N., Contro, S., Capposso, P. \& Sehator, F. (2005). Anti bacterial activity of Cuminum Cyminum L, and corum Carvia L., essential oils . Journal Agric food chem. , 53(1), $57-61$.

32- Fabio, A., Corona, A, Forte, E. \& Quaglio, P. (2003). Inhibitory Activity of spices and essential oils of psychrophilic Bacterial . Journal ,The new Microbiologica, 26(1), 115 - 120 .
33- Wienck, A., Boeck, I., Eisold, S., Klar, E. \& Linnebacher, M. (2009). Identifizierung eines immunogenen T-Zell-Epitopes des MSIZielantigens U79260(FTO) . Journal Biomed Biotechnd , 38, 29 - 30.

34- Rimutè, M. (2012). Potenial pathogens of common caraway (Carum carvi L.) seeds and search for measures suppressing their spread. Journal Agriculture., 99, 2 , 179-188. 35- Olatunde, A. \& Dikwa, M. A. (2014). Qualitative and Quantitive Anylysis of Phytochemicals of Loranthus bengwensis Leaf. IntRJPharmSci, 5(1),10-12. 36Thatte, U., Bagadey, S. \& Dahanakar, S. ( 2000). Modulation of programmed cell death by medicinal plants. Send to Cell Mol Biol (Noisyle-grand)., 46(1), 199-214. 
Table 1: Quantity and percentage of extracts

\begin{tabular}{ccc|c} 
NO. iolvent used in extraction & Extracted amount $(g)$ & \multicolumn{1}{c}{ Extract (\%) Of Yield } \\
\hline 1 & Cold water & 6.06 & 12.12 \\
2 & Hot Water & 4.4 & 8.8 \\
3 & Methanol & 2.6 & 5.2 \\
4 & Ethanol & 1.5 & 3 \\
5 & Hexane & 1 & 2 \\
6 & Oil & 1.7 & 3.45
\end{tabular}

Table 2: Detection of active compounds in the seeds of the caraway plant using water and alcohol extracts

\begin{tabular}{|c|c|c|c|c|c|c|}
\hline \multirow[t]{3}{*}{ No } & \multirow{3}{*}{ Active compound } & \multicolumn{5}{|c|}{ Result of detection } \\
\hline & & \multicolumn{2}{|c|}{ Aqueous extract } & \multicolumn{3}{|c|}{ Alcoholic extract } \\
\hline & & Cold Water & Hot Water & Methanol & Ethanol & $\begin{array}{c}\text { Hexa } \\
\text { ne }\end{array}$ \\
\hline 1 & Saponine & + & - & + & + & + \\
\hline 2 & $\begin{array}{l}\text { Glycosides \& } \\
\text { Carbohydrates }\end{array}$ & + & - & - & - & - \\
\hline 3 & Tannins & + & + & + & + & - \\
\hline 4 & Alkaloids & + & - & - & - & + \\
\hline 5 & Flavonoids & + & + & + & + & - \\
\hline 6 & Resins & + & + & + & + & + \\
\hline 7 & Turbines & + & - & + & - & + \\
\hline 8 & Amino acids & - & + & + & + & + \\
\hline 9 & Phenols & + & + & + & + & - \\
\hline
\end{tabular}




\begin{tabular}{ccc|c} 
NO. & Compound & min $/ R T$ & Area $\%$ \\
\hline \multicolumn{1}{c}{ D-Limonene } & 5.915 & 12.73 \\
2 & Sylvestrene & 7.123 & 9.10 \\
3 & Trans-B-ocimene & 11.230 & 0.04 \\
4 & Y-Terpinene & 11.715 & 0.06 \\
5 & Linalool & 14.137 & 0.14 \\
6 & Cis-limonene oxide & 14.326 & 0.20 \\
7 & Trans limonene oxide & 14.819 & 0.26 \\
8 & Teans dihydro corvone & 15.097 & 0.24 \\
9 & Carvone & 16.767 & 76.78 \\
10 & Perillaldehyde & 17.224 & 0.24 \\
11 & Nonadecanioic acid & 33.706 & 0.4
\end{tabular}

Table (3) Percentage of some chemical compounds found in caraway seed oil 


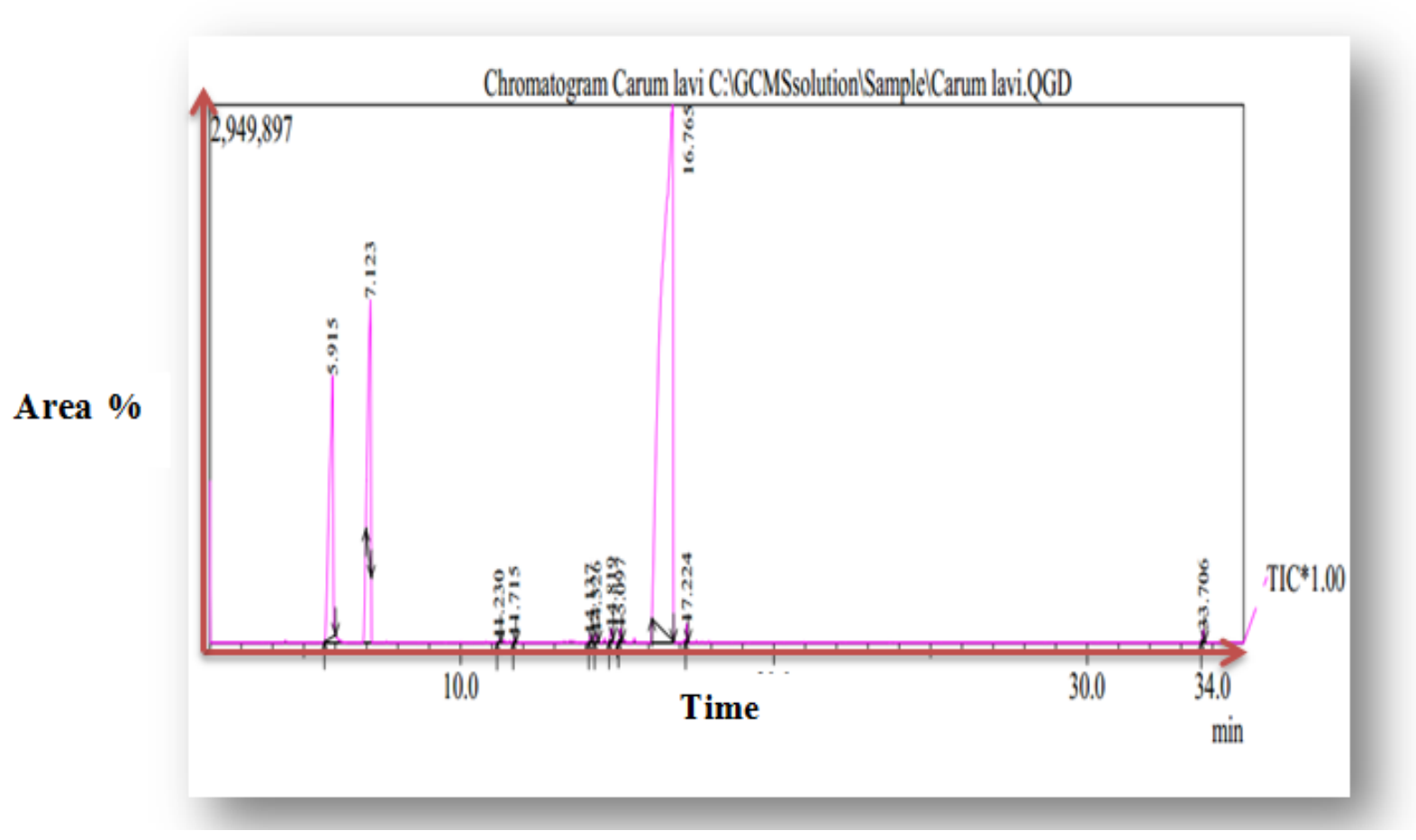

Figure 1:Graphical curve of compounds separated from Caraway oil by gas chromatography (GC-Mass)

Table 4: Percentage of inhibition of L20B cells

\begin{tabular}{cc|c} 
Extracts & Concentration & Inhibition ratio( IR\%) \\
\hline Cold water & 12.5 & 0 \\
Hot Water & 25 & 0 \\
Methanol & 12.5 & 0 \\
& 25 & 0 \\
Ethanol & 12.5 & 13.33 \\
& 25 & 12.12 \\
Hexane & 12.5 & 29.7 \\
& 25 & 0 \\
Oil & 12.5 & 0 \\
& 25 & 0
\end{tabular}


25

0

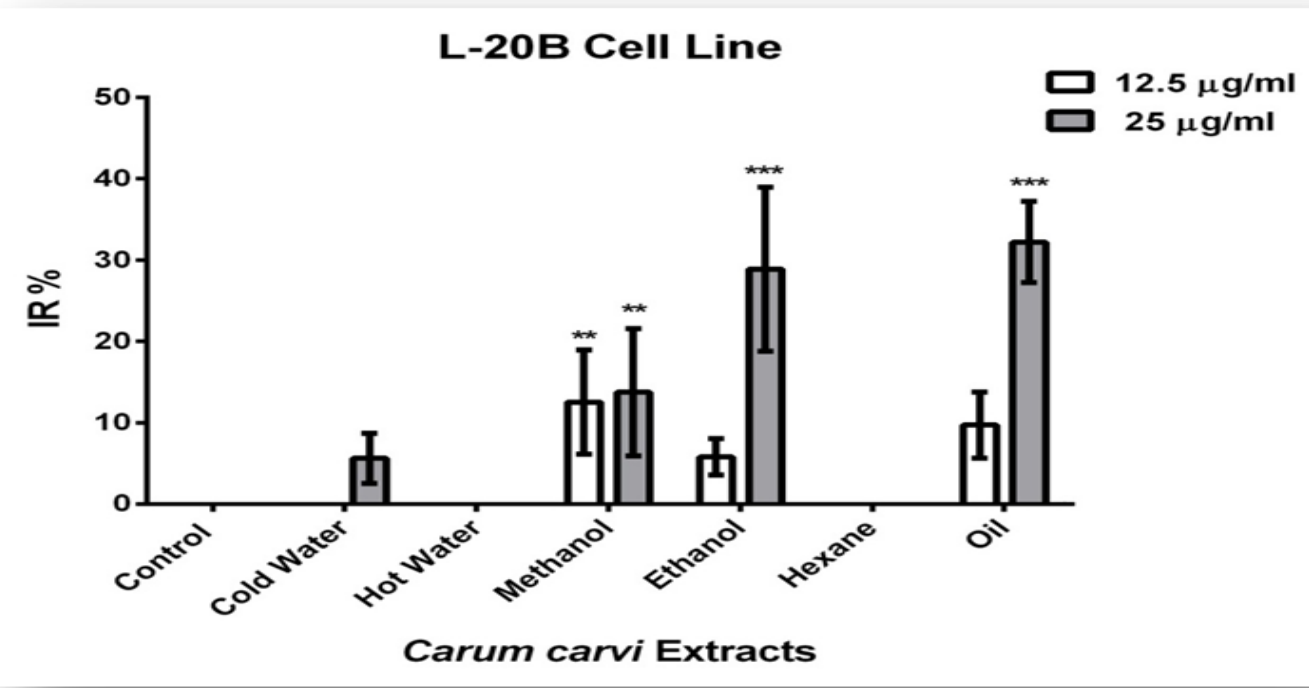

$\mathrm{P}<0.05, * *=\mathrm{P}<0.01, * * *=\mathrm{P}<0.001=*$

Figure 2: Effect of caraway extract on L20B cells

Table 5 : Percentage of inhibition of SR cells

\begin{tabular}{cc|c} 
Extracts & Concentration & Inhibition ratio (IR\%) \\
\hline Cold water & 12.5 & 0 \\
Hot Water & 25 & 0 \\
& 12.5 & 73.28 \\
Methanol & 25 & 58.6 \\
& 12.5 & 0 \\
Ethanol & 25 & 0 \\
& 12.5 & 11.2 \\
Hexane & 25 & 0 \\
& 12.5 & 19.8
\end{tabular}



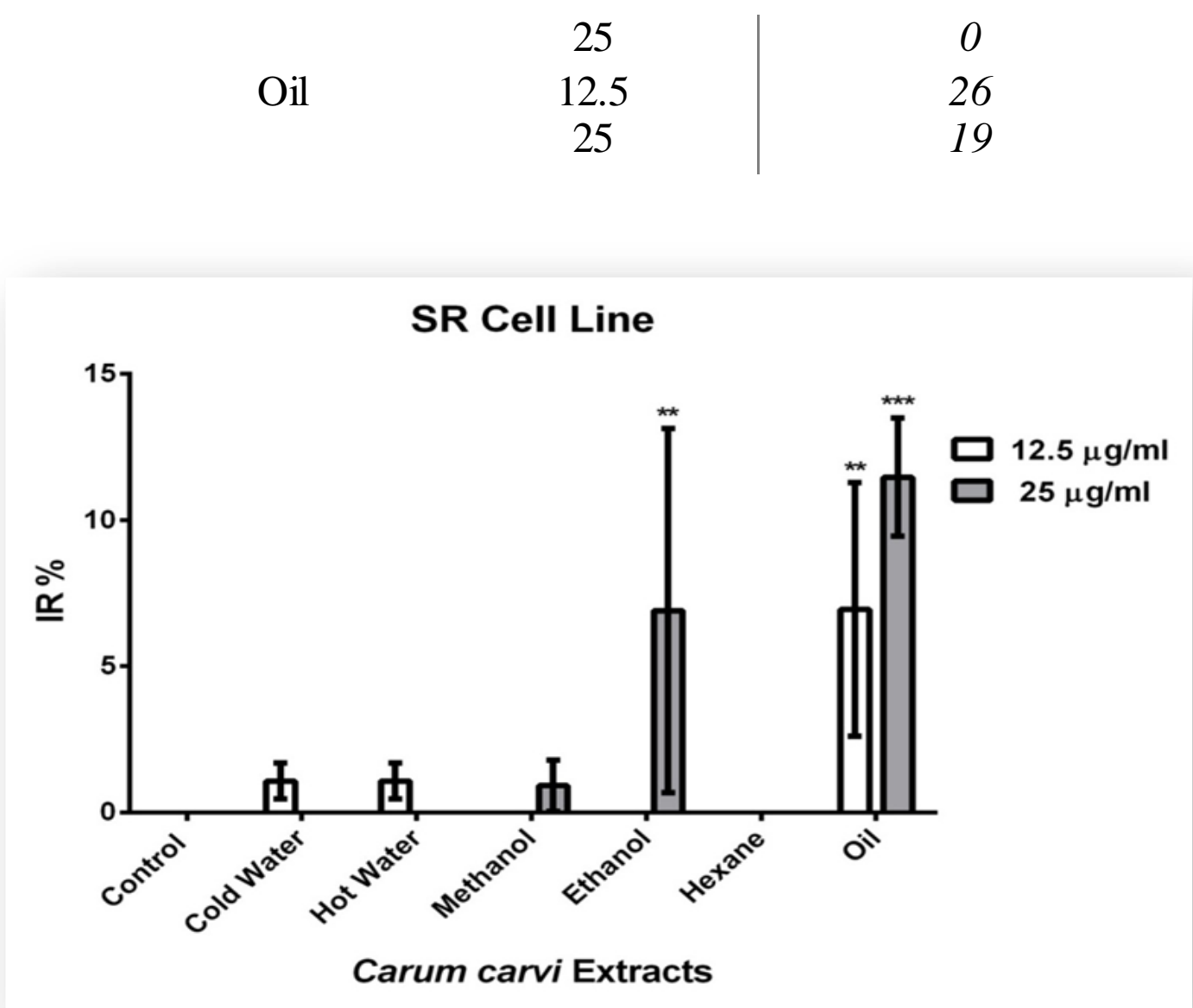

$$
*=\mathrm{P}<0.05, * *=\mathrm{P}<0.01, * * *=\mathrm{P}<0.001
$$

Figure 3: shows the effect of caraway extracts on SR cells 